\title{
Expression and polymorphism of defensins in farm animals
}

\author{
Emilia Bagnicka, Nina Strzałkowska, Artur Jóźwik, Józef Krzyżewski, Jarosław Horbańczuk \\ and Lech Zwierzchowski ${ }^{\bowtie}$
}

Institute of Genetics and Animal Breeding in Jastrzębiec, Polish Academy of Sciences, Wólka Kosowska, Poland

\begin{abstract}
Due to their activity against bacteria, viruses, and fungi, antimicrobial peptides are important factors in the innate resistance system of humans and animals. They are called "new generation antibiotics" for their potential use in preventive and therapeutic medicine. The most numerous group of antimicrobial peptides is a family of cationic peptides which include defensins and cathelicidins. Among them the most common are peptides with a beta-sheet structure containing three intra-molecular disulphide bonds, called defensins, comprising three classes: alpha, beta, and theta. The class of beta-defensins is the largest one. Their transcripts have been found in many tissues of humans and animals. The aim of this paper is to present the current knowledge about antimicrobial peptides from the defensin family in farm animals, their expression, polymorphism, as well as the potential of their use as genetic markers of health and production traits.
\end{abstract}

Keywords: farm animals, defensins, expression, polymorphism

Received: 25 August, 2010; revised: 04 November, 2010; accepted: 01 December, 2010; available on-line: 06 Decemebr, 2010

\section{INTRODUCTION}

Antimicrobial peptides (AMPs) and proteins are important players in immunological systems of humans and animals. They stimulate the innate immunity of an organism and demonstrate a direct activity against bacteria, enveloped viruses, and fungi (Kagan et al., 1990; Yang et al., 1999; Anbu et al., 2003; Pawlik et al., 2009). As summarized by Kamysz et al. (2003) and then by Lai and Gallo (2009) the numerous actions of the antimicrobial peptides such as cathelicidins, alpha- and beta-defensins include influence on: expression of adhesion molecules, production of adrenocorticoids, secretion of chloride ions, angiogenesis, wound repair, and DNA synthesis. They have also been shown to interact with cell membrane receptors, influencing diverse cellular processes such as releasing of cytokines, chemotaxis and antigen presentation (Lai \& Gallo, 2009). The diversity of the biological activities of antimicrobial peptides was confirmed by a study carried out on human beta-defensin- 2 (hBD-2) by Baroni et al. (2009). The hBD-2 stimulated in vitro endothelial cell migration, proliferation and formation of capillary-like tubes. Alpha- and beta-defensins have chemotactic activity also for immature dendritic cells (Lehrer \& Ganz, 2002).

A majority of antimicrobial peptides demonstrate similar modes of action, based on an interaction with cell membranes of microorganisms. The interaction results in causing the membrane permeability by piercing and formation of channels by which the contents of a cell leaks (so called "aggregate channel model" or "barrel-stave model"), or total disruption of a microorganism's membrane (so called "carpet model") (Brogden, 2005; Shai, 1999; Helmerhorst et al., 1999). However, it can not be excluded that other, still unknown mechanisms of their antimicrobial activity exist (Gordon \& Romanowski, 2005; Lai \& Gallo, 2009).

The average concentration of defensins in human tissues ranges from 10 to $100 \mu \mathrm{g} / \mathrm{ml}$, while in granules of leucocytes where they are stored the concentration reaches as much as $>10 \mathrm{mg} / \mathrm{ml}$. The biological activity of defensins depends strongly on their concentration (Ganz, 2004). As an example, at low concentrations $(<10 \mu \mathrm{g} / \mathrm{ml})$ alpha-defensins stimulate expression of adhesion molecules in human endothelial cells and cytokine production in human monocytes. Also at low concentration they are chemo-attractants for immune cells (monocytes, T-lymphocytes, dendric cells) and/or inhibitors of protein kinase $\mathrm{C}$ activity. Human neutrophil peptides (HNPs; also called alpha-defensins), at concentrations between 10- and 100-fold below those required for antimicrobial activity, show chemotactic activity for $\mathrm{CD}^{2} 5 \mathrm{RA}^{+}$and $\mathrm{CD}^{+}{ }^{+} \mathrm{T}$ lymphocytes. The hBD-2 effect on chemotaxis and wound healing depends on its concentration, with a maximum effect at $500 \mathrm{ng} / \mathrm{ml}$ and more. But the minimal hBD-2 concentration needed to kill bacteria appears much higher in vitro then in vivo. The reason for this may be that in a living organism it is coexpressed as a group with other AMPs that act synergistically (Lai \& Gallo, 2009).

e-mail: I.zwierzchowski@ighz.pl

Abbreviations: AMPs, antimicrobial peptides; AvBD, avian betadefensins; BAC, bacterial artificial chromosome; BBD, bovine betadefensins; BLAD, bovine leucocyte adhesion deficiency; BNBD, bovine neutrophil beta-defensins; BTA, Bos taurus autosome; CBD-103 canine beta-defensin 103; CDGs, combined defensin genotypes; DEFA, equine alpha-defensin; EBD, enteric beta-defensin; EBD-P and EBD-P2, enteric beta-defensin pseudogenes; ECA, Equus caballus autosome; GAL/CHP, gallinacins, chicken beta-defensins; GBD-1 and GBD-2, goat beta-defensin 1 and 2; H5N1, subtype of influenza A virus, also known as "bird flu"; hBD-2, human beta-defensin 2; HDP, host defense peptide; HSA, Homo sapiens autosome; LAP, lingual antimicrobial peptide; LD, lethal dose; LPS, bacterial lipolysaccharide; Mc1r, melanocortin 1 receptor; MDCK, cell line derived from canine kidney; Osp-1 and Osp-2, ostrich beta-defensins = ostricacins-1 and 2; pBD, porcine beta-defensins; RFLP, restriction fragment length polymorphism; $\mathrm{RH}$, radiation hybrid; RTD theta-defensins, mini-defensins or demidefensins; SBD-1 and SBD2, sheep beta-defensin 1 and 2; SCC, somatic cell count; SMAP-29, sheep myeloid antimicrobial peptide-29 (sheep cathelicidin); SNP, single nucleotide polymorphism; STR, short tandem repeat; TAP tracheal antimicrobial peptide; THP1, THP2, THP3 and GPV-1, turkey's beta-defensins; 5'UTR or $3^{\prime} U T R, 5^{\prime}$ or $3^{\prime}$ untranslated region 
As reviewed by Ganz (2004), defensins at concentrations ranging from 1 to $10 \mu \mathrm{g} / \mathrm{ml}$ exhibit a broad spectrum of antimicrobial activity that includes Gram-negative and Gram-positive bacteria and fungi. At $25 \mu \mathrm{g} / \mathrm{ml}$ they stimulate DNA synthesis. At very high concentrations $(\geq 100 \mu \mathrm{g} / \mathrm{ml})$ these peptides stimulate keratinocyte growth and cause the lysis of microbes and some tumor cells (Biragyn et al., 2002; Lehrer \& Ganz, 2002; Kamysz et al., 2003; Ganz et al., 2004; Wiechuła et al., 2006). As emphasized by Wiechuła et al. (2006) natural antimicrobial peptides may be especially effective due to their inter-leucocyte location; these cells are drawn to infection sites and inflammation stimulates synthesis of certain peptides in the epithelium.

Alpha- and beta-defensins, unlike theta-defensins, are sensitive to salt concentration. They show reduced antimicrobial activity even in the presence of physiological salt (Ganz \& Lehrer, 1998; 1999; Tang et al., 1999). Increasing concentrations of salts and plasma proteins inhibit the antimicrobial activity of defensins in a manner that is specific to both the particular defensin and its microbial target.

Based on their total net charge antimicrobial peptides can be differentiated into anionic and cationic ones (Hancock, 1997; Lehrer \& Ganz, 1999). Cationic peptides constitute a very large group of antimicrobial factors consisting of several families, including defensins and cathelicidins. The most common family are peptides with beta-sheet structures stabilised by intra-molecular disulphide bonds between cysteine residues. They are called defensins and comprise three classes: alpha, beta and theta.

Beta-defensins have been isolated from neutrophils and other leucocytes, epithelial cells, blood plasma, urine and many tissues of vertebrates, including humans and domestic animals (Brogden et al., 2003; Schneider et al., 2005). Peptides of this subfamily are also found in in- vertebrates and plants (Lynn \& Bradley, 2007). Alphadefensins were first found in primates (humans, rhesus), lagomorphs and rodents, but then also in other mammals (Looft et al., 2006; Bruhn et al., 2007; Lynn \& Bradley, 2007). They are widely distributed in phagocytes (neutrophils and macrophages), in Paneth's cells and on the mucosal surface of epithelia (Ganz \& Lehrer, 1995, Schneider et al. 2005). Alpha-defensins comprise about $5-7 \%$ of all proteins present in mature neutrophils and $30-50 \%$ in azurophile granules (Rice et al., 1987). The last class identified in animals (only in rhesus monkey) were cyclic mini-defensins, called theta-defensins, demidefensins or retrocyclins (RTD-1 and RTD-2), reported by Tang et al. (1999). Liang et al. (2010) tested the ability of retrocyclin 2, to protect chicken embryos from infection by a highly pathogenic strain of avian influenza virus H5N1. A fragment of the retrocyclin 2 gene cloned into a eukaryotic expression vector was shown to protect chicken cells and embryos from infection through inhibition of $\mathrm{H} 5 \mathrm{~N} 1$ replication and transcription.

Defensins contribute to the innate immunity, acting immediately after microbial invasion not only by direct killing of the pathogens but also as immune regulators (Lai \& Gallo, 2009). Defensins are ancient components of immunity systems; they originated before the emergence of eukaryotes (Nava et al., 2009). The beta-defensin family is phylogenetically older than alphadefensins, while theta-defensins are thought to arise in evolution from two mutated alpha-defensin genes (Patil et al., 2004). The Patil's paper provides evidence of true orthology among defensins and analyzes the molecular diversity of a mammalian-specific domain responsible for their antimicrobial activity. Specifically, this analysis demonstrates that eleven amino-acid residues of the antimicrobial domain have been subject to positive selection to confer specialization of different AMPs. These data support the notion that natural selection acts as an evolu-

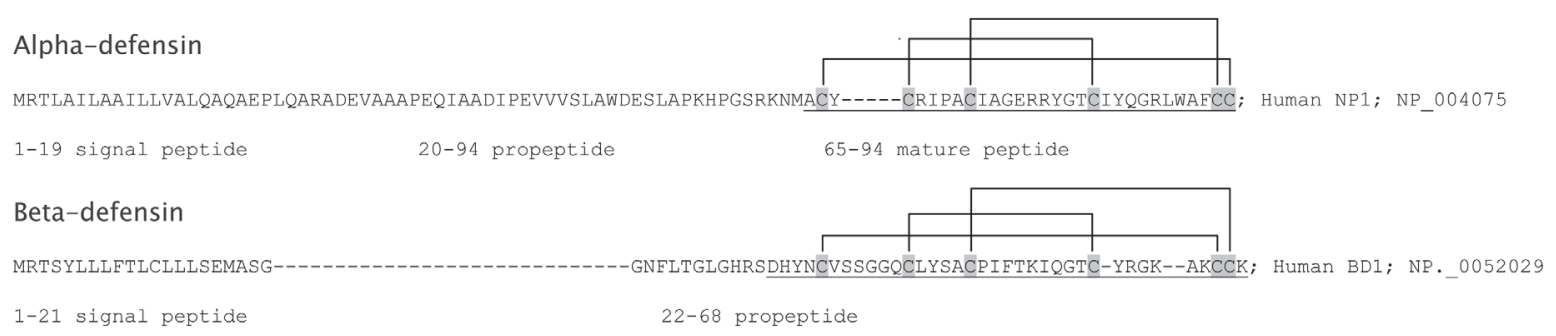

33-68 mature peptide

Theta-defensin

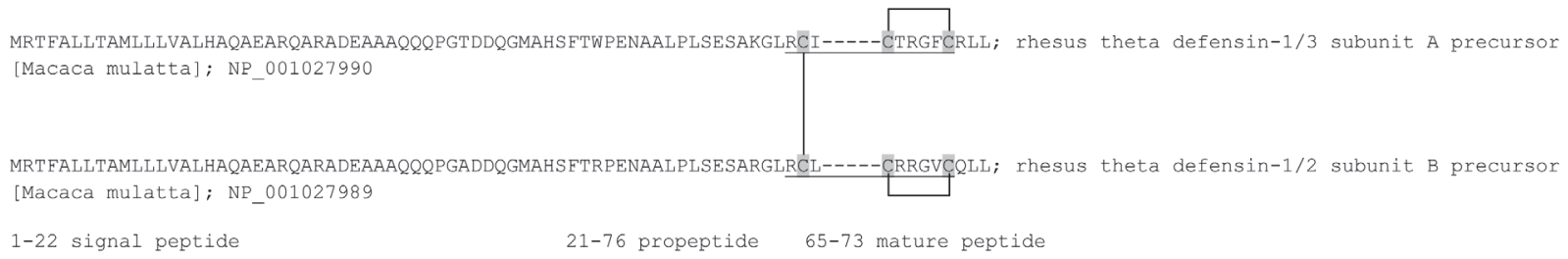

Mature theta-defensin sequence

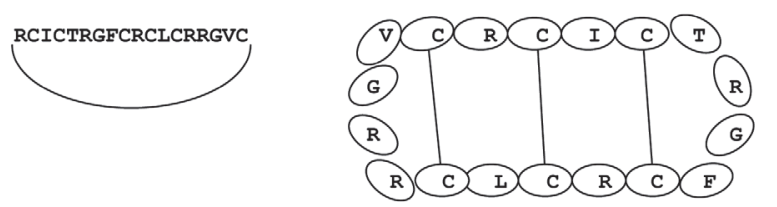

Figure 1. Amino-acid sequence of mammalian alpha, beta and theta defensins; braces and shading show disulfide bonds and cysteines involved 


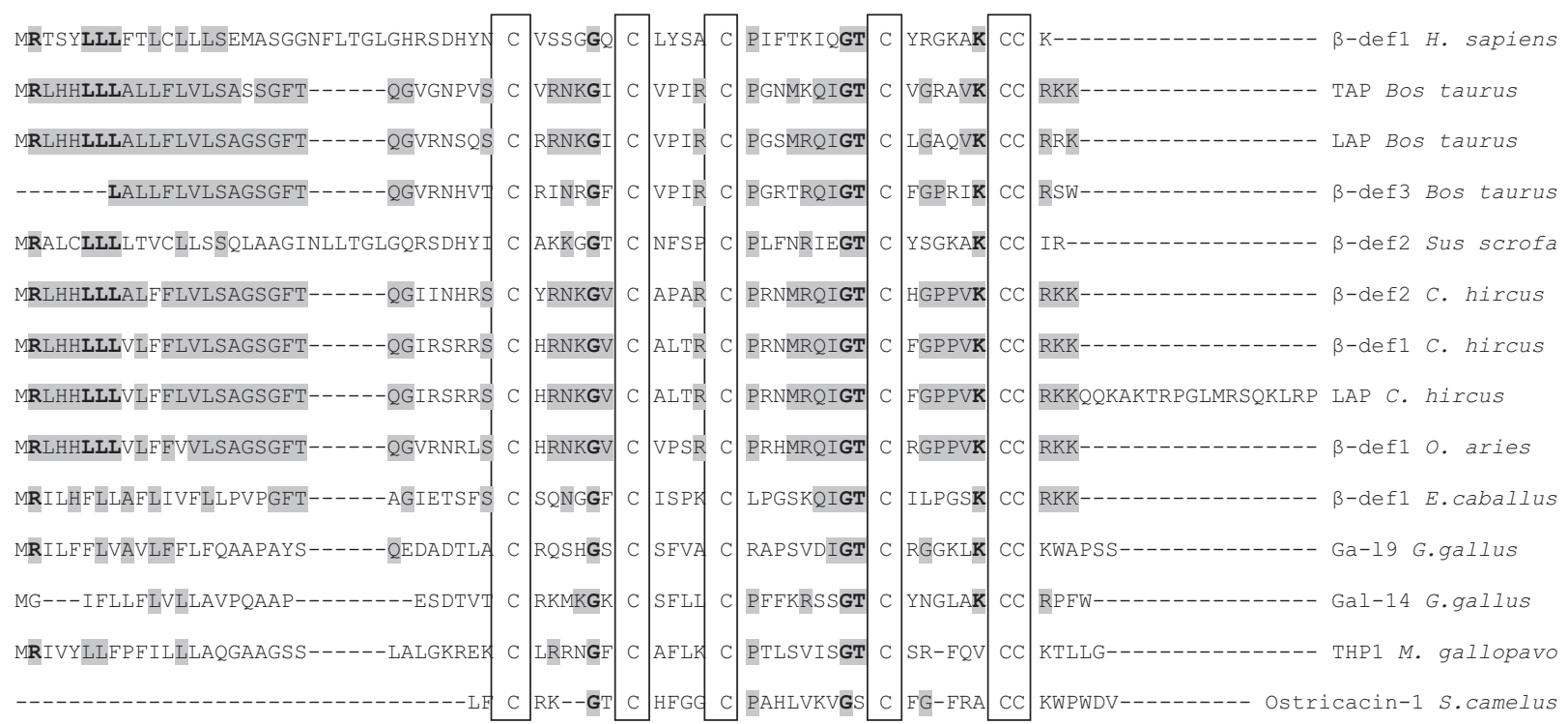

Figure 2. Alignment of amino-acid sequences of mammalian and avian defensis. Shaded - highly conserved amino acids; framed cysteines participating in disulfide bonds.

tionary force driving the diversification of defensins, and may help to elaborate more effective antibiotics.

All mammalian defensins are small (about $10 \mathrm{kDa}$ ), cationic and amphiphilic peptides. Most defensins have six cysteine residues and three disulphide bonds which are not essential for the antimicrobial activity but confer high resistance to bacterial proteolysis (Nava et al., 2009). The three disulphide bonds are crucial for determining and maintaining the core configuration of their structure (Fig. 1 and 2). Alpha- and beta-defensins have similar three-dimensional structure and antimicrobial activity (Schneider et al., 2005) but they differ markedly in the location of the intra-molecular disulphide bridges, structure of their precursors and sites of expression (Lehrer \& Ganz, 1999). They derive from an ancestral gene which probably existed before reptiles and birds diverged (Zhao et al., 2001).

The amphiphilic structure appears to be critical for permeabilization of pathogens' membrane. In mammals all known alpha- and beta-defensin genes have two exons (Mallow et al., 1996; Huttner et al., 1998b). The first exon encodes 5'UTR and leader domain of the pre-propetide. The second exon encodes the mature peptide. All known avian beta-defensin genes have four exons (Soman al., 2009) (Fig. 3).

Functions other than antimicrobial have been attributed to mammalian defensins. In domestic dog, apart from Agouti and melanocortin 1 receptor $(M c 1 r)$, a third gene (K locus) controls pigment type-switching. Candille et al. (2007) have identified the $K$ locus as beta-defensin 103 (CBD-103) gene and showed that its protein product binds with high affinity to Mc1r having a direct strong effect on coat pigmentation of dogs.

Of all antimicrobial peptide families defensins are the most common. The presence of alpha- and beta-defensin transcripts has been documented in many tissues of different farm animal species. Therefore, the aim of the present review is to summarize the current knowledge about these antimicrobial peptides in farm animals (mammals and birds), their expression, polymorphism, as well as the potential of their application as genetic markers of health and production traits in animal breeding.

\section{DEFENSINS IN CATTLE}

The first defensin ever identified in a farm animal was a 38-amino-acid peptide isolated from bovine trachea, named tracheal antimicrobial peptide (TAP) (Diamond et al., 1991; Bals et al., 1998). This peptide demonstrated germicidal activity against Gram-positive and Gram-negative bacteria as well as against fungi - Candidia albicans (Diamond et al., 1991, 1993). The highest level of TAP mRNA was found in mucosal membrane of the bovine respiratory tract. The transcript level showed a strong increase after infection by bacteria or stimulation by bacterial lipolysaccharide (LPS; Diamond et al., 2000). Tarver et al. (1998) also demonstrated TAP gene transcript in the distal part of the small intestine.

In 1993 Selsted and co-workers presented data about thirteen structurally homologous cationic peptides isolated from the cytoplasmic fraction of bovine blood neutrophils rich in granules. These peptides, containing 38-42 amino acids with a highly conserved sequence, demonstrated in vitro antibacterial activity. Their consensus sequence was different from that of other defensins known then in other mammalian species. The anti-bacterial activity of some of those bovine neutrophil peptides equalled that of the most active rabbit neutrophil defensin NP-1 (one of the alpha-defensins). Due to the considerable similarity to the rabbit defensins as regards the structure and function, and to differentiate them from the alpha-defensin class, the authors suggested the name "beta-defensin" for the newly discovered family of antimicrobial peptides.

From the group of bovine neutrophil peptides reported by Selsted et al. (1993), the best known are beta-defensins 4 and 5 (BNBD-4 and BNBD-5). Ryan et al. (1998) showed their strong constitutive expression in macrophages located on the surface of bovine pulmonary alveoli. They were found irrespectively of the presence of pro-inflammatory factors, such as LPS, or air pollutants, residual oil fly ash (ROFA), $\mathrm{SiO}_{2}$, or asbestos, resulting in an inflammation of the respiratory tract and stimulating release of cytokines. Goldammer et al. (2004) observed a high level of BNBD-5 mRNA in epithelium 


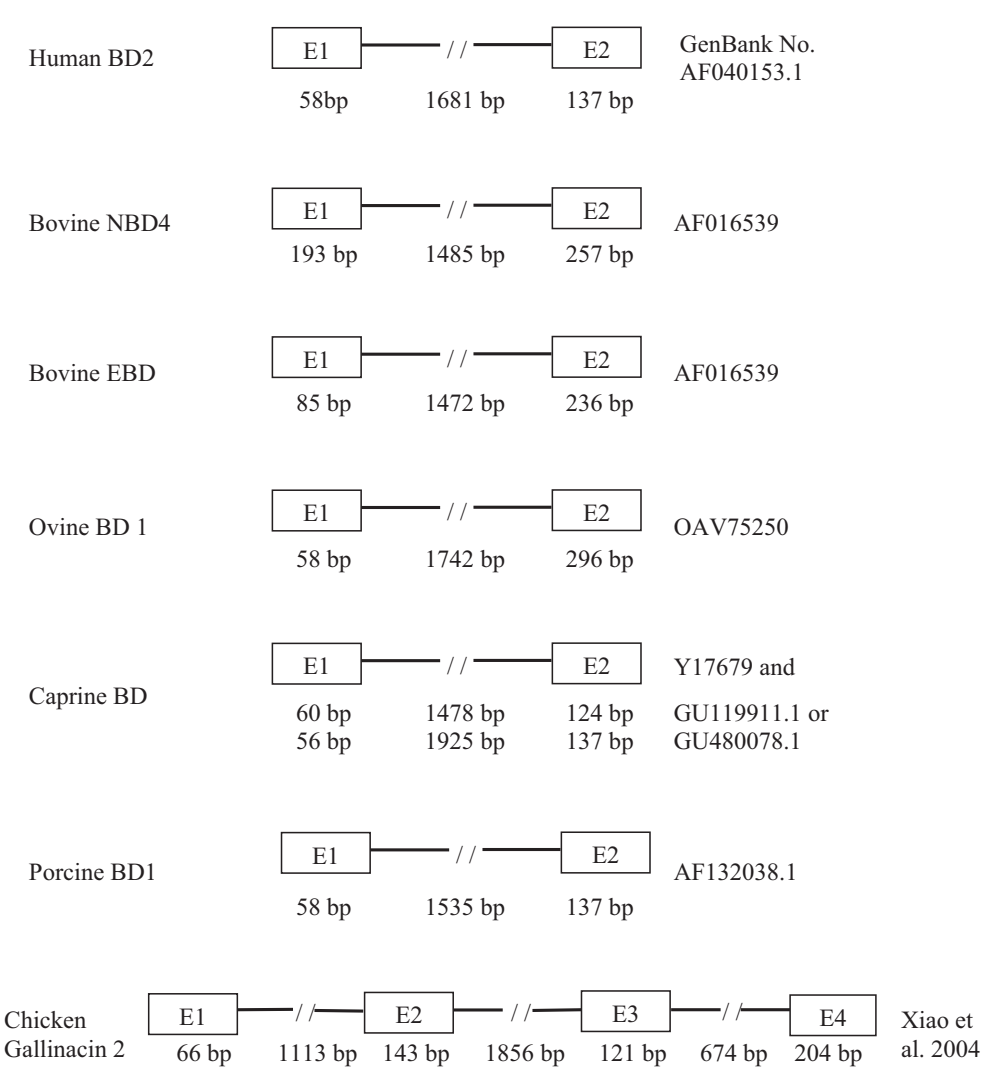

Figure 3. Structure of mammalian and avian genes encoding beta-defensins. [E], exons; $-/ /-$, introns.

of bacteria-infected mammary glands of cows. Low levels of BNBD-3, BNBD-4, BNBD-9 mRNAs were found in the distal part of the small intestine, while a high abundance of BNBD-3 and BNBD-9 transcripts was observed in bone marrow (Tarver et al., 1998). Moreover, Roosen et al. (2004) identified six new defensin genes (DEFB401-DEFB405 and LAP-like), highly homologous to the earlier known beta-defensin genes and two pseudogenes, named EBD-P and EBD-P2. Transcripts encoding several anti-microbial peptides (defensins): BNBD-3, BNBD-9, BNBD-12, DEFB-401, TAP, as well as the described below LAP and DEFB1 (enteric defensin), were detected in mammary gland of lactating cows. TAP mRNA was identified only in tissues from healthy mammary glands. Other mRNAs were found in both healthy and bacteria-infected udders (Roosen et al., 2004). Our studies demonstrated beta-defensin 4 (BNBD-4) transcripts in somatic cells derived from cow milk (Bagnicka et al., 2006).

The lingual antimicrobial peptide (LAP) is another bovine defensin; it was found in squamous tongue epithelium (Schonwetter et al., 1995) and in trachea (Russell et al., 1996), where its mRNA level was low but detectable. It was also found in distal part of the small intestine by Tarver et al. (1998). Schonwetter et al. (1995) showed that expression of LAP mRNA in the tongue is induced principally around wounds. A high abundance of LAP mRNA was reported in stomach, colon, rectum, nostrils, trachea, skin and some other tissues (Table 1). Schonwetter et al. (1995) have demonstrated a significant increase of LAP transcript in ileum tissues from cows infected by Mycobacterium paratuberculosis and in bronchial epithelium from calves infected by Pasteurella haemolytica. In cows suffering from bovine leucocyte adhesion deficiency (BLAD) syndrome an increased in level of LAP
mRNA was found in bronchial epithelium and sub-mucosal gland after inoculation with $P$. haemolytica in comparison with healthy tissues (Stolzenberg et al., 1997). In the already mentioned studies by Roosen et al. (2004) a high content of LAP mRNA was found both in healthy and in infected mammary gland tissues. By contrast, Swanson et al. (2004) showed expression of this defensin only in infected mammary tissues and concluded that it was induced by mastitis. In somatic cells isolated from milk, LAP gene transcript was found only if the cell number was increased above the normal level $(>100000 / \mathrm{ml}$ of milk), indicating inflammation of the mammary gland (Bagnicka et al., 2006).

Enteric beta-defensin (EBD) was first isolated from bovine alveolar macrophages, colon, and small intestine (Tarver et al., 1998). A high level of EBD mRNA was demonstrated in the distal part of the small intestine. Moreover, infection of calves with Cryptosporidium parvum resulted in a 5-10-fold increase of the EBD mRNA in the intestine, compared with that observed in control animals. In our studies EBD gene transcript was found in somatic cells obtained from milk of healthy cows and those with clinical mastitis (Bagnicka et al., 2006).

Cormican et al. (2008) reported a novel group of bovine beta-defensins (BBD-119, BBD-120, BBD-122, BBD-122a, BBD-123, BBD-124 and BBD-142) and found their transcripts abundant in uterine tissues. They also found that BBD-123 inhibits growth of several bacteria species, especially that of Escherichia coli and Listeria monocytogenes. Another study showed the presence of transcripts of $L A P, T A P, B N B D-4, B N B D-5$, and BNBD123 in bovine uterus - in endometrial epithelial cells treated with E. coli LPS, as well as the LAP and TAP transcripts in uterine stromal cells (Davies et al., 2008).

Aono et al. (2006) compared the gene structure and amino-acid sequence of bovine beta-defensin 1 (BBD-1) with its human counterpart (hBD-1) and with other bovine beta-defensins. They showed that bovine BD-1 gene has one long intron, as large as the intron of the human gene ( 8547 bp in hBD-1 vs. 6962 in BBD-1), about five-fold longer then introns of other known bovine beta-defensin genes. Bovine BD-1 shows a $57 \%$ similarity in amino acid sequence to $\mathrm{hBD}-1$ and $34 \%$ to bovine LAP, while LAP shows 78, 81, 86 and $89 \%$ similarity to BNBD-4, DEF401, EBD and TAP, respectively.

By means of fluorescence in situ hybridization beta-defensin genes have been mapped to bovine chromosome 27 (Gallagher et al., 1995). The mapping data suggested clustering of the genes defining the location of DEFB@ to $27 \mathrm{q} 13 \rightarrow \mathrm{q} 14$. Recently, it was shown that coat color in cattle co-segregated with markers in a region of chromosome 27 (BTA27) that include the beta-defensin 103 gene (Dreger \& Schmutz, 2010).

Das et al. (2005) cloned and characterized a beta-defensin mRNA from distal ileum of water buffalo (Bubalus bubalis). A sequence analysis indicated 29 nucleotide substitutions vs. cattle enteric beta-defensin (EBD) mRNA 
Table 1. Expression of defensins in different farm animals species

\begin{tabular}{|c|c|c|c|}
\hline Species & Peptide or gene name & Localization in tissues (peptide or mRNA) & Sources \\
\hline \multicolumn{4}{|c|}{ Beta-defensins } \\
\hline \multirow[t]{6}{*}{ Cattle } & TAP & $\begin{array}{l}\text { mucosal membrane of respiratory tract, distal } \\
\text { part of small intestine, bovine uterus - endo- } \\
\text { metrial cells, stromal cells }\end{array}$ & $\begin{array}{l}\text { Tarver et al., 1998; Diamond et } \\
\text { al., 2000; Roosen et al., 2004; } \\
\text { Davies et al., } 2008\end{array}$ \\
\hline & $\begin{array}{l}\text { Bovine neutrophil beta-defen- } \\
\text { sins BNBD1-12, }\end{array}$ & $\begin{array}{l}\text { mammary gland epithelium, milk somatic cells, } \\
\text { distal part of small intestine, bone marrow, ute- } \\
\text { rus, macrophages }\end{array}$ & $\begin{array}{l}\text { Ryan et al., 1998; Tarver et al., } \\
\text { 1998; Goldammer et al., 2004; } \\
\text { Bagnicka et al., } 2006\end{array}$ \\
\hline & LAP & $\begin{array}{l}\text { squamous tongue epithelium, trachea, distal } \\
\text { part of small intestine, palate, oesophagus, } \\
\text { stomach, colon, rectum, nostrils, trachea, con- } \\
\text { junctiva, skin, columnar epithelium of intestinal } \\
\text { follicles, cerebral choroid plexus, cerebral cortex, } \\
\text { cerebral Purkinje cells, sub-mucosal gland, milk } \\
\text { somatic cells, uterus, placenta }\end{array}$ & $\begin{array}{l}\text { Schonwetter et al., 1995; Russell } \\
\text { et al., 1996; Tarver et al., 1998; } \\
\text { Stolzenberg et al., 1997; Ro- } \\
\text { osen et al.,2004; Bagnicka et } \\
\text { al., 2006; Davies et al., } 2008\end{array}$ \\
\hline & Enteric beta-defensin (EBD) & $\begin{array}{l}\text { alveolar macrophages, colon, small intestine, } \\
\text { milk somatic cells }\end{array}$ & $\begin{array}{l}\text { Tarver et al., 1998; Bagnicka et } \\
\text { al., } 2006\end{array}$ \\
\hline & $\begin{array}{l}\text { BBD119, BBD120, BBD122, } \\
\text { BBD122a, BBD123, BBD124, } \\
\text { BBD142 }\end{array}$ & uterus & Cormican et al., 2008 \\
\hline & DEFB401, DEFB405, & mammary gland & Roosen et al., 2004 \\
\hline \multirow{2}{*}{ Sheep } & SBD-1, & $\begin{array}{l}\text { epithelial cells, rumen, reticulum, omastum, } \\
\text { small and large intestine, tongue, trachea }\end{array}$ & Huttner et al., 1998a \\
\hline & SBD-2 & $\begin{array}{l}\text { epithelial cells, rumen, reticulum, omastum, ton- } \\
\text { gue, trachea, ileum, large intestine }\end{array}$ & Huttner et al., 1998a \\
\hline \multirow[t]{2}{*}{ Goat } & GBD-1 & $\begin{array}{l}\text { milk somatic cells, tongue, trachea, bronchi, } \\
\text { lungs }\end{array}$ & $\begin{array}{l}\text { Zhao et al., 1999; Bagnicka et } \\
\text { al., } 2005\end{array}$ \\
\hline & GBD-2 & $\begin{array}{l}\text { milk somatic cells, stomach, jejunum, ileum, lar- } \\
\text { ge intestine, rectum }\end{array}$ & $\begin{array}{l}\text { Zhao et al., 1999; Bagnicka et } \\
\text { al., } 2005\end{array}$ \\
\hline \multirow[t]{10}{*}{ Pig } & pBD-1 & tongue, trachea, intestine, epithelial tissue & $\begin{array}{l}\text { Shi et al., 1999; Zhang et al., } \\
1999\end{array}$ \\
\hline & pBD2 & $\begin{array}{l}\text { liver, intestine (duodenum, jejunum, ileum), } \\
\text { lungs, bone marrow }\end{array}$ & Sang et al., 2006 \\
\hline & pBD3 & bone marrow, liver, lungs, lymphatic system & \\
\hline & pBD4 & lungs, epididymis & \\
\hline & pBD104 & pancreas, liver teste & \\
\hline & pBD108 & liver and epididymis & \\
\hline & pBD114 & $\begin{array}{l}\text { ileum, pancreas, liver, lungs, tissues of the male } \\
\text { reproductive system }\end{array}$ & \\
\hline & pBD123 & $\begin{array}{l}\text { ileum, pancreas, lungs, tissues of the male repro- } \\
\text { ductive system }\end{array}$ & \\
\hline & pBD125 & lungs, thymus, epididymis & \\
\hline & pBD129 & epididymis, duodenum, jejunum, pancreas, skin & \\
\hline Horse & horse beta-defensin-1 & $\begin{array}{l}\text { many tissues and organs, including heart, pan- } \\
\text { creas, lymphoglandula, liver, lungs and digestive } \\
\text { tract (small and large intestine) }\end{array}$ & Davis et al., 2004 \\
\hline \multirow{5}{*}{ Chicken } & GAL 1 and GAL2 & heterophils & van Dijk et al., 2007 \\
\hline & GAL3 & $\begin{array}{l}\text { tongue, bursa Fabricii, trachea, skin, oesophagus, } \\
\text { air sacs, large intestine, kidneys }\end{array}$ & Zhao et al., 2001 \\
\hline & Gal6 & digestive tract & \\
\hline & Gal11 & small intestine, liver, gallbladder, spleen & van Dijk et al., 2007 \\
\hline & Gal13 & colon & \\
\hline \multirow[t]{3}{*}{ Duck } & AvBD-2 & $\begin{array}{l}\text { bone marrow, spleen, kidney, lung, brain, bursa } \\
\text { Fabricii, ovary }\end{array}$ & Ma et al., 2009a, 2009b \\
\hline & AvBD-9 & liver, kidney, crop, trachea & \\
\hline & AvBD-10 & liver, kidney & \\
\hline \multicolumn{4}{|c|}{ Alpha-defensins } \\
\hline Horse & DEFA1 & intestine & Bruhn et al., 2007, 2009a, b \\
\hline
\end{tabular}


(sequence identity $86.2 \%$ ). The sequence identity was $92.1 \%, 81.6 \%$, and $84.6 \%$ with bovine LAP, bovine TAP, and goat BD-2, respectively. The deduced amino acid sequence encoded a 64-amino acid precursor peptide.

\section{DEFENSINS IN SHEEP}

In sheep, two beta-defensin genes have been identified and named SBD-1 and SBD-2 (Huttner et al, 1998a, 1998b). Iannuzzi et al. (1996) reported that sheep betadefensin genes are located on chromosome $24 \mathrm{q}$, while Huttner et al. (1998b) claimed their localization on chromosome 26. SBD-1 and SBD-2 pre-propeptides contain 64 amino acids. Their nucleotide sequence is identical in $87 \%$, while the degree of identity of the amino acid sequence is $78 \%$, which indicates a positive selection pressure. The transcripts of both ovine defensins were found in epithelial cells, but their levels differed between organs and between individual animals. The highest transcript abundance was found in the rumen as well as in small and large intestine (Table 1). In rumen the highest $S B D$ 1 and SBD-2 mRNA levels were recorded during the first 6-8 weeks of life. Studies conducted on pregnant sheep demonstrated significant differences in expression levels of both defensins between tissues and between animals in the same period of pregnancy. The highest expression tended to appear during the third trimester. The highest level of SBD-1 gene transcripts in adult sheep was observed in the tongue, large intestine epithelium and in trachea. A lower mRNA level was recorded in rumen epithelium. In ileum the SBD-1 transcript was not found. In turn, the $S B D-2$ gene transcript was shown only in the ileum and large intestine. No expression of beta-defensins 1 and 2 was recorded in sheep pancreas, heart or liver (Huttner et al., 1998a).

Luenser et al. (2005) identified thirteen beta-defensin encoding sequences in six animal species belonging to the tribe Caprini, including sheep (Ovis aries) and goat (Capra bircus). In this number, two had already been known as sheep and goat beta-defensins 1 and 2. All the remaining beta-defensin sequences were identified as variants of SBD-1 and SBD-2 (sheep) or GBD-1 and GBD-2 (goat). A high conservation of beta-defensin exons was demonstrated; therefore discrimination of the different beta-defensin genes was possible only due to intron-specific differences.

\section{DEFENSINS IN GOAT}

Two beta-defensins have been identified in goats GBD-1 and GBD-2. Genes of their precursors - preproGBD-1 and pre-proGBD-2 - were $96.8 \%$ identical in nucleotide and $88.2 \%$ in amino-acid sequence (difference of eight amino acids), again indicating a positive selection pressure. GBD-1 transcript was found in the tongue, trachea, bronchi and lungs. That of GBD-2 was found in the stomach, large intestine, and rectum (Zhao et al., 1999; Table 1). Anbu et al. (2003) studying cationic peptides isolated from goat tongue, demonstrated their germicidal activity against both Gram-positive (Staphylococcus aureus) and Gram-negative (E. coli) bacteria.

In our studies we found transcripts of GBD-1 and GBD-2 in kidneys, trachea, tongue epithelium, spinal cord, and in mammary gland of non-lactating (dry) goats (Bagnicka et al., 2005). The highest mRNA levels of both beta-defensins were recorded in the trachea, slightly lower in tongue, mammary gland and kidneys, and the lowest in the spinal cord. Moreover, a varying level of defensin transcripts was found in the goat milk cells, depending on the somatic cell count (SCC); the higher the SCC the higher was the level of the transcripts.

The mRNA sequence of a gene encoding caprine lingual antimicrobial peptide — LAP was cloned and characterized (Sharma et al., 2006; GenBank DQ836129). The information on the goat LAP includes the whole cds and translation product. Our comparison of the nucleotide sequence of $L A P$ and GBD-1 genes and the amino-acid sequences of goat defensins has revealed that GBD-1 is 18 amino acids shorter than that of LAP. This difference may be due to the presence of the stop codon UAG at position 209-211 in GBD-1 mRNA. In the LAP mRNA counterpart, this triplet (CAG) encodes glutamine. Therefore, the sequence of the first 64 amino acids is identical in both LAP and beta-defensin-1 (GBD-1). The nucleotide sequence of GBD-1 and LAP mRNAs differs only at two nucleotide positions (209 and 238, according to GenBank DQ836129). Thus, our analysis of the mRNA and peptide sequences suggests that in goat, GBD-1 and LAP may be products of two recently duplicated genes of which one acquired the nonsense mutation to create the TAG stop codon (Bagnicka et al., submitted for publication).

\section{DEFENSINS IN PIG}

Until recently, only one beta-defensin $p B D-1$ transcript was detected in pig tongue epithelium by Northern blot technique (Shi et al., 1999). This defensin is active against E. coli, Salmonella typhimurium, L. monocytogenes and C. albicans. Thus, it is likely that it co-creates the antimicrobial barrier of the tongue and oral cavity in pigs. The gene encoding pBD-1 consists of two short exons (82 $\mathrm{bp}$ and $234 \mathrm{bp}$ ) separated by a 1535 bp-long intron and is located on chromosome $15 \mathrm{q} 14-\mathrm{q} 15.1$. An expression of $p B D-1$ mRNA was demonstrated during inflammation and bacterial infections of the tongue, trachea, and intestine epithelium (Zhang et al., 1999). Only recently did Sang et al. (2006) record transcripts of eleven other betadefensins in different porcine tissues. Abundant $p B D-2$ transcript was found in the liver, intestine, lungs and bone marrow; $p B D-3$ - in bone marrow, liver, lungs, and lymphatic system; $p B D-4$ - in lungs and epididymis; $p B D-104$ - in pancreas, liver and testes; $p B D-108$ - in liver and epididymis; $p B D-114$ - in ileum, pancreas, liver, lungs and tissues of the boar reproductive tract ( $\mathrm{Ta}$ ble 1). The presence of $p B D-123$ transcript was recorded in the same tissues (with the exception of liver) in which $p B D-114$ mRNA occurred. The transcript of the $p B D$ 125 gene was detected in lungs, thymus and epididymis, while that of $p B D-129$ - in epididymis, duodenum, jejunum, pancreas, and skin (Table 1). Transcription of the pEP2C pseudogene was detected in the thymus, skin, testes, and certain secretions of the epididymis, but not in other tissues.

Recently, about 30 host defense peptides (HDPs) have been identified in the pig and their structure and functions partially characterized (Sang \& Blecha, 2009). The antimicrobial activity of the porcine peptides has been evaluated extensively against a broad spectrum of microorganisms in vitro and for their protective role in vivo. Veldhuizen et al. (2008a) studied the antimicrobial activity of $\mathrm{pBD}-2$, a porcine beta-defensin produced in the intestine. The peptide showed high antimicrobial activity 
against a broad range of pathogenic bacteria. The highest activity was observed against $S$. typhimurium, L. monocytogenes and Erysipelothrix rhusiopathiae. Salmonellosis is a serious problem in pig breeding, therefore more detailed studies were conducted on the antimicrobial activity of pBD-1 and pBD-2 against $S$. typhimurium (Veldhuizen et al., 2008a; 2008b). A 4-8 $\mu \mathrm{M}$ concentration of pBD-2 was sufficient to lyse these bacteria in $3 \mathrm{~h}$. At higher ionic strengths the antimicrobial activity of $\mathrm{pBD}-2$ decreased, and disappeared completely at the physiological concentration of $\mathrm{NaCl}(150 \mathrm{mM})$.

Inter-breed differences have been found in beta-defensin gene expression levels in various pig tissues (Chen et al., 2010). In most tissues the abundance of $p B D-1,2$ and 3 mRNAs was higher in Meishan pigs than in the Duroc x Yorkshire x Landrace crossbreds. As the authors concluded, the higher expression of pBDs might be the reason why Meishan pigs have a higher resistance to disease than other pig breeds.

Galindo et al. (2009) have analyzed global gene expression profiles in the spleen of European wild boar naturally infected with Mycobacterium bovis using real-time RTPCR analysis and an expression microarray (Pigoligoarray) representing 20400 genes. Immune response genes were the most differentially expressed. Beta-defensin 129, T-cell surface glycoprotein CD8 and B-cell receptor-associated protein 29 were overexpressed in naturally infected animals compared with non-infected. That study has identified new mechanisms by which naturally infected wild boar respond to $M$. bovis infection and how the pathogen circumvents the host immune responses to establish infection.

\section{DEFENSINS IN HORSE}

Milenkovic et al. (2002) analyzed a horse bacterial artificial chromosome (BAC) DNA library and found a gene having 93\% nucleotide sequence identity with those encoding goat and human beta-defensins. In the horse genome it was localised on the long arm of chromosome 9, band 14 (GTG staining). This was the first report on a defensin gene in horse.

In 2004 Davis and co-workers reported a full sequence of horse beta-defensin-1 cDNA. This defensin is about $60 \%$ identical with defensins of other animal species and humans. Horse BD-1 cDNA shows the highest level of identity with pig BD-1 (69.5\%). The same authors demonstrated expression of beta-defensin-1 mRNA in many tissues and organs of the horse, including heart, pancreas, liver, lungs and the digestive tract.

The equine defensin gene cluster has been localized on ECA $27 q 17$ using fluorescence in situ hybridization and confirmed by RH-mapping of a marker from the DEFB1 (AY170395) gene (Looft et al., 2006). This is in agreement with the results of Swinburne et al. (2006) indicating homology of the defensin-harboring human autosome 8 (HSA 8) with equine autosomes - ECA 9 and ECA 27.

Looft et al. (2006) using a horse BAC clones identified nine genes, of which six showed a high sequence similarity with the gene of human beta-defensin 4. For most of those genes no transcripts were detected in horse tissues. The authors identified also ten pseudogenes of high homology with human beta-defensin 4 (DEFB-4). Moreover, they identified a sequence showing high similarity with human alpha-defensin genes. That novel gene was named DEFA-5L; its pseudogene (DEFA-5LP) was also identified, without experimentally proven expression. These could be the first alpha-defensins found outside the species belonging to primates, lagomorphs (rabbit and hare) and rodents. Further studies found another thirty-eight transcripts of alpha-defensins in equine intestinal. At least 20 of them may code for functional peptides. For 14 genes present in the horse genome, however, no transcripts were found and 10 transcripts have no matching genomic sequence. These findings indicate that the assembly of the horse alpha-defensin gene cluster is not yet complete. To date, in addition to the species listed above, alpha-defensin genes have also been identified in opossum, elephant and hedgehog tenrec (Bruhn et al., 2009b).

Studies by Bruhn et al. (2007; 2009a, 2009b) confirmed the presence of alpha-defensins in equine intestine. The first indentified equine alpha-defensin - DEFA1 - has a broad spectrum of antimicrobial activity, with the highest sensitivity at peptide concentrations $<1 \mu \mathrm{M}$ (LD90) shown by Gram-positive bacteria.

\section{DEFENSINS IN POULTRY}

Until recently, only peptides from the beta-defensin family have been identified in birds (Harwig et al., 1994). But now several avian cathelicidins family members are also known (Meade et al., 2009). The first beta-defensins identified in the chicken were gallinacins: GAL1/CHP1, GAL1 alpha/CHP2, GAL2 and GAL3, while in turkeys - THP1, THP2, THP3 and GPV-1. These peptides contain 36-39 amino acids and have a strong cationic nature due to the presence of numerous lysine and arginine residues (Brogden et al., 2003). GAL3 was isolated from chicken (Gallus gallus) epithelium. In healthy birds this peptide was found in many organs and tissues ( $\mathrm{Ta}$ ble 1). The expression of GAL3 in the trachea increased significantly after infection with Haemophilus paragallinarun, while in tongue, bursa Fabricii and oesophagus it remained constant (Zhao et al., 2001). Some of the peptides found in chicken (CHP1 and 2) and turkey (THP1) are active against $S$. aureus and E. coli, while THP2 and THP3 — only against $S$. aureus; they also show a fungicidal activity. However, no activity of those peptides was observed against the virus causing contagious bronchitis in birds (Evans et al., 1995).

Thirteen beta-defensin genes have been described in the chicken - GAL1-13, and showed to comprise a gene cluster. Polymorphisms of those genes and especially of three of them - GAL11, GAL12 and GAL13 were correlated with the resistance of the animals to Salmonella enteritidis infection (Hasenstein \& Lamont, 2007; Derache et al., 2009a). Transcripts of Gal1 and 2 were found in heterophils, Gal11 — in small intestine, liver, gallbladder and spleen, Gal13 — in colon, while Gal6 - in the digestive tract (Table 1). The sequence of the GAL6 gene showed the most similarity with human $B D-1$ (43\% identity), with bovine neutrophil beta-defensin genes (43 to $45 \%$ ), and with sheep beta-defensin genes $(41 \%)$ (van Dijk et al., 2007). According to the current knowledge, the avian beta-defensin family (previously referred to as gallinacins) consists of 14 peptides ( $A v B D 1-14$ ) encoded by genes located on chromosome 3 in a single 85-kb region (Meade et al., 2009).

Gong et al. (2010) have found in the chicken genome, three copies of a gene encoding gallins, antimicrobial peptides closely related to avian beta-defensins, of a new avian antimicrobial peptide family. 
Gallins contain six cysteine residues found in all defensins, although their spacing differs. They were expressed in tubular cells of the magnum region of oviduct and their mRNA levels were 10000 times greater in magnum than in shell gland. These peptides have potent antimicrobial activity against E. coli and form antimicrobial barrier in the avian innate immune system, particularly in the egg white.

Three biologically active beta-defensins have been purified by chromatography from chicken bone marrow: avian beta-defensins AvBD-1, AvBD-2 and AvBD7 (Derache et al., 2009b). Their antibacterial activities were assessed against a large panel of Gram-positive and Gram-negative bacteria. All three defensins displayed similar activity against Gram-positive strains, but AvBD1 and AvBD-7 exhibited stronger activity against Gramnegative bacteria then AvBD-2. Those authors also studied expression of two beta-defensins, AvBD-1 and AvBD-2C, in embryonic intestinal cells isolated from chickens of two inbred lines of different susceptibility to S. enteritidis. Primary intestinal cell cultures were found to differentially express the two beta-defensin genes, depending on the line. Furthermore, $S$. enteritidis interfered with AvBD-2 expression only in the cells from the susceptible line 15I, suggesting that these antimicrobial peptides may play a crucial role in immunoprotection against bacteria.

Ebers et al. (2009) determined mRNA expression profiles of 14 avian beta-defensins (AvBDs) in primary chicken oviduct epithelial cells before and after infection with Salmonella enterica. The infection temporarily inhibited expression of certain AvBDs but induced expression of other minimally expressed defensins. Distinct expression patterns of innate immune genes, including Toll-like receptors, AvBDs, and both pro- and anti-inflammatory cytokines during early chicken embryonic development, were shown by Meade et al. (2009). Expression of AvBD-9 was significantly increased on day 9; and AvBD-10 was increased on day 12 in embryo abdomen, relative to day 3 expression levels.

The presence of two beta-defensins in ostrich - ostricacins-1 and 2 (Osp-1 and Osp-2) has been described (Sugiarto \& Yu, 2007). The ability to disrupt bacterial membrane integrity by those defensins was shown to be weaker than that of sheep cathelicidin SMAP-29, but stronger than that of human neutrophil peptide-1 HNP1 (alpha-defensin).

Two beta-defensins homologous to other avian beta-defensins were isolated from duck liver by Ma et al. (2009a, 2009b); they were named duck AvBD-9 and AvBD-10. The AvBD-9 mRNA was differentially expressed in many tissues of ducks, with especially high levels of expression in the liver, kidney, crop, and trachea. Duck AvBD-10 was only expressed in the liver and kidney (Table 1). Both defensins exhibited antimicrobial activity against several bacterial strains: Bacillus cereus, Pasteurella multocida, E. coli, Salmonella choleraesuis, and S. aureus. Soman et al. (2009) identified and characterized a duck beta-defensin 2 homologue gene with a 195 -base pair open reading frame, which was $83 \%$ identical with chicken and $85 \%$ with turkey beta-defensin 2. The peptide encoded by this gene had the classical beta-defensin core motif formed by a betasheet-rich structure. Apart from moderate expression in the kidney, lung, brain, bursa Fabricii and ovary; duck $A v B D-2$ mRNA showed a very high constitutive expression in bone marrow and spleen, indicating that it is a myeloid defensin.

\section{DEFENSINS AS GENETIC MARKERS}

The nucleotide sequence polymorphism of human defensin genes has been studied intensively. Single nucleotide polymorphisms (SNPs) of beta-defensins have been correlated with increased susceptibility to certain diseases. Associations have been reported between beta-defensin gene polymorphisms and susceptibility to diabetes, melanoma, oral squamous carcinoma, prostate cancer, Crohn's disease, psoriasis, dermatitis, leprosy, and infectious diseases - Helicobacter pylori-induced gastritis, HIV infection, and many others. Numerous studies have reported altered expression of beta-defensins in cancers suggesting their involvement in carcinogenesis. At least in one case, the functionality of a mutation in a defensin encoding gene has been shown in that it modifies the gene expression level (Sun et al., 2006). In the human beta-defensin 1 ( $h B D-1)$ gene, a candidate tumor suppressor, the $\mathrm{C} / \mathrm{G}$ polymorphism at position -688 upstream of the ATG translation start codon affected $h B D$ 1 gene promoter activity in a reporter gene (luciferase) transcription test in DU145 and TSU-Pr1 cells. The transcription rate was 40 to $50 \%$ lower when the promoter variant with the $G$ nucleotide was used compared with the wild-type promoter variant with nucleotide C. In addition, the $\mathrm{C} / \mathrm{G}$ polymorphism at position -44 modified the transcriptional activity of the $h B D-1$ promoter; the $\mathrm{C} \rightarrow \mathrm{G}$ transversion enhanced transcription level up to 2.3 -fold. The effect of the $-44 \mathrm{C} / \mathrm{G}$ transversion on the human beta-defensin $1(h B D-1)$ gene expression was then confirmed in many different types of normal and cancerous cells.

Very little study has been carried out on the polymorphism of defensin genes in farm animals and its effect on disease susceptibility and production traits. Hasenstein and Lamont (2007) analyzed two lines of chickens for association of gallinacin genotypic variation with resistance to $S$. enteritidis infection. In the search for nucleotide sequence polymorphism, thirteen chicken gallinacin genes, which are the functional equivalents of mammalian beta-defensins, were sequenced from individuals of different hen breeds and production lines. On average, seventeen SNPs per kilobase were found in the chicken gallinacin gene cluster. The SNP genotypes of the GAL11, GAL12, and GAL13 genes showed an association with bacterial load in the cecal content suggesting a role of the gallinacins in the defense of poultry against enteric pathogens. The authors concluded that the polymorphisms of the chicken gallinacin (beta-defensin) genes GAL11, GAL12 and GAL13 could be used as a marker assisting in selection of poultry for resistance to S. enteritidis infection.

In our earlier study (Ryniewicz et al., 2003) we revealed twenty different combined genotypes (CDGs) in bovine defensin genes. We showed that several CDGs significantly associated with dairy performance traits of Holstein-Friesian cows, as well as with the milk somatic cell count (SCC), a well recognized indicator of clinical or sub-clinical mastitis in cow udders. The results speak for using defensin genes as markers of disease susceptibility and productivity of cows. This could help in early selection of high yielding animals with high resistance to mastitis. Our results were confirmed by WojdakMaksymiec et al. (2006) who investigated associations between the same combined defensin genotypes and somatic cell count (SCC) in Jersey cows. The highest SCC was found in the milk of cows with the A1-B1-C1C2 genotype, whereas the lowest in cows with the genotype 
A2-B1B2C1C2. Also studied were associations between the defensin genotypes and milk production traits. Combined genotypes were found to associate with daily milk yield and with fat and protein content in milk.

Later on we found ten SNPs in the bovine BNBD-4 gene intron by sequencing of the gene from ten HolsteinFriesian (HF) cows (Bagnicka et al., 2007; 2008). Two SNPs generated new endonuclease digestion sites and therefore could easily be genotyped using the restriction fragment length polymorphism (RFLP) technique. This enabled genotyping of a numerous cohort of dairy HF cows and studying associations of the BNBD-4 gene polymorphism with milk production traits and resistance/ susceptibility to mastitis. The $\mathrm{A} \rightarrow \mathrm{C}$ transversion at position 1674 (according to GenBank No. AF008307; recognized with RFLP-BsrI) was associated with daily milk, fat and protein yield, average daily fat, protein, lactose, and dry matter contents. On the other hand the $\mathrm{C} \rightarrow \mathrm{T}$ transition at position 2239 (RFLP-NlaIII) affected milk fat, protein and lactose contents and also the number of somatic cells in the milk. Therefore, they were shown to be promising bio-markers for early selection of dairy cows less susceptible to mastitis and producing milk of good quality (Bagnicka et al., 2007; 2008). In general, an important message from our studies is that the defensins may be used as genetic markers in breeding programs aimed at selecting highly productive dairy cattle with increased resistance to udder infections.

Recently, two microsatellites (short tandem repeats STRs) and five SNPs newly found in the bovine beta defensin 103 (DEFB103) gene were used as genetic markers for linkage mapping with red coat phenotype in Holstein cattle (Dreger \& Schmutz, 2010). The variant red (VR) phenotype, caused by a mutation in melanocortin 1 receptor, was shown to co-segregate with markers in a region of chromosome 27 that included DEFB103. One haplotype was inherited in VR cattle in a 6-generation pedigree.

\section{PERSPECTIVES}

One of the largest and most studied group of antimicrobial peptides are defensins, especially the beta-defensin subfamily. In addition to the beta-defensins many other types of anti-microbial peptides are known, including alpha- and theta-defensins, cathelicidins and others. Defensins are common in plants and animals. The high variety of the antimicrobial peptides is obviously a response of organisms to the diversity of pathogens. The antimicrobial peptides are thought to have diverged during evolution under the pressure of natural selection to maintain a host-pathogen balance (Nava et al., 2009). On the other hand, the universal character of the antimicrobial peptides contributed to their conservation throughout evolution.

The antimicrobial peptides that participate in the innate immunity of most metazoa justly hold claim to the name of "new generation antibiotics". They could be used both in preventive and therapeutic treatments (Kamysz et al., 2003; Koczulla \& Bals, 2003). The benefits of the use of antimicrobial peptides in therapy include the wide spectrum of their activity, direct antimicrobial action, stimulation of phagocytosis, and anti-inflammatory activity (Kamysz et al., 2003). Despite having an ancient origin the defensins remain the most efficient component of antimicrobial defense because they have not induced resistance in most microorganisms. This is possibly due to their high diversity. The high diversity of antimicrobial peptides and their several modes of action against bacteria might have impeded the evolution of resistance in natural bacterial populations. On the other hand, an increasingly wide future therapeutic use of only some of AMPs may lead to the evolution of bacterial resistance (Perron et al., 2006; Nava et al., 2009).

Intensive studies are being conducted in medical research centres and pharmaceutical companies aimed at production of synthetic or recombinant peptides in order to use them in human treatment. Some antimicrobial peptides are in the pre-clinical and clinical phases of study. Most, but not all such studies, have shown positive results. Their results seem very promising and researchers are beginning to see the reality of using such peptides in human medicine (Gordon \& Romanowski, 2005; Jenssen et al., 2006; Wiechuła et al., 2006). Studies have been conducted on the synergistic effects of defensins and classical antibiotics (Leszczyńska, 1998) and the use of defensins as immunostimulators to induce the natural resistance of the human organism (Gordon \& Romanowski, 2005). Understanding all aspects of the biological activity of antimicrobial peptides, then the synthesis or production of recombinant peptides is very important, but is only the first step that must be taken. Using exogenous peptides in human treatment is a challenge as it is still necessary to develop appropriate methods for their administration. It is also still necessary to develop ways of avoiding their possible toxicity to the host organism. Moreover, production of such compounds is very expensive. So far, their use has been limited to local treatments (creams, ointments, mouth rinsing preparations). Antimicrobial peptides administered, for example, intravenously would have to permeate healthy tissues to reach infection sites, thus exerting undesirable side effects. Moreover, the peptides are rather large molecules. They have a strong positive charge and enter tissues slowly. Some promising signals have emerged indicating the possibility of solving these problems.

Antimicrobial peptides, especially defensins, constitute an important innate, non-specific system in the natural defense in animals and human. No doubt, their use in human therapy is only a question of time. Studies on antimicrobial peptides carried out in farm animals are still a step behind those in humans or laboratory animals. So far, there are no plans to use such peptides to treat diseases in farm animals. Nevertheless, the results of recent studies, including ours, indicate that the polymorphism of beta-defensin genes may be a marker in selection for milk production performance and/or susceptibility to mastitis of farm ruminants (Ryniewicz et al., 2003; Bagnicka et al., 2007; 2008) and those of chicken AMPs - in selection for resistance to Salmonella infections (Hasenstein \& Lamont, 2007). To reach these goals, further association studies are needed to be carried out on numerous groups of farm animals of different species, supported by basic research of biological activities of defensin variants. The most challenging seem to be efforts to elucidate the causative relationships between the nucleotide sequence polymorphisms in defensin genes and the anti-microbial functions of encoded peptides. For such studies advanced molecular methods of functional genomics, such as transcriptomics, proteomics and nextgeneration sequencing, would be very helpful.

\section{Acknowledgements}

Studies were realized within the project "BIOŻYWNOŚĆ" (BIOFOOD — innovative, function- 
al products of animal origin) no. POIG.01.01.02-014090/09 co-financed by the European Union from the European Regional Development Fund within the Innovative Economy Operational Programme 2007-2013.

\section{REFERENCES}

Anbu KA, More T, Kumar A (2003) Isolation and characterisation of cationic antibacterial proteins and peptides from goat tongue epithelium. Indian J Anim Sci 73: 1307-1311.

Aono S, Li Ch, Zhang G, Kemppainen RJ, Gard J, Lu W, Hu X, Schwartz DD, Morrison EE, Dykstra Ch, Shi J (2006) Molecular and functional characterization of bovine beta-defensin-1. Vet Immunol Immunopathol 113: 181--190.

Bagnicka E, Flisikowski K, Strzałkowska N, Krzyżewski J, Prusak B, Sakowski T, Zwierzchowski L (2005) Expression level of goat $\beta$ defensin genes in different goat tissues and in somatic cells of goat milk - preliminary study. Proceedings of the XI Baltic Animal Breding and Genetics Conference, May 2005, Palanga, Lithuania, pp. 144-146.

Bagnicka E, Szreder T, Strzałkowska N, Krzyżewski J, Zwierzchowski L (2006) Expression of defensin genes in milk somatic cells of cows and goats in connection with health status of mammary gland. Sympozjum Sprawozdawcze: ,Molekularne i fizjologiczne aspekty rozrodu i żywienia zwierzate", March 2-3, Jabłonna, p. 2 (in Polish).

Bagnicka E, Strzałkowska N, Flisikowski K, Szreder T, Jóźwik A, Prusak B, Krzyżewski J, Zwierzchowski L (2007) The polymorphism in the $\beta 4$-defensin gene and its assotiation with production and somatic cell count in Holstein-Friesian cows. I Anim Breed Genet 124: 150-156.

Bagnicka E, Strzałkowska N, Szreder T, Prusak B, Jóźwik A, Kościuczuk E, Krzyżewski J, Zwierzchowski, L (2008) A/C polymorphism in the $\beta-4$ defensin gene and its association with phenotypic and breeding values of milk production traits in Polish-Friesian cows. Anim Sci Pap Rep 26: 239-250.

Bals R, Wang X, Wu Z, Freeman T, Bafna V, Zasloff M, Wilson JM (1998) Human $\beta$-defensin 2 is a salt-sensitive peptide antibiotic expressed in human lung. J Clin Invest 102: 874-880.

Baroni A, Donnarumma G, Paoletti I, Longanesi-Cattani I, Bifulco K, Tufano MA, Carriero MV (2009) Antimicrobial human betadefensin-2 stimulates migration, proliferation and tube formation of human umbilical vein endothelial cells. Peptides 30: 267-272.

Biragyn A, Ruffini PA, Leifer CA, Klyushnenkova E, Shakhov A, Chertov O, Shirakava AK, Farber JM, Segal DM, Oppenheim JJ, Kwak LW (2002) Toll-like receptor 4-dependent activation of dendric cells by beta-defensin 2. Science 298: 1025-1029.

Brogden KA (2005) Antimicrobial peptides: pore formation or metabolic inhibitors in bacteria? Nat Rev Microbiol 3: 238-250.

Brogden KA, Ackermann M, McCray Jr. PB, Tack BF (2003) Antimicrobial peptides in animals and their role in host defence. Int $J$ Antimicrob Agents 22: 465-478.

Bruhn O, Regenhard P, Michalek M, Paul S, Gelhaus C, Jung S, Thaller G, Podschun R, Leippe M, Groetzinger J, Kalm E (2007) A novel horse alpha-defensin: gene transcription, recombinant expression and characterization of the structure and function. Biochem J 407: 267-276.

Bruhn O, Cauchard J, Schlusselhuber M, Gelhaus C, Podschun R, Thaller G, Laugier C, Leippe M, Grötzinger J (2009a) Antimicrobial properties of the equine alpha-defensin DEFA1 against bacterial horse pathogens. Vet Immunol Immunopathol 130:102-106.

Bruhn O, Paul S, Tetens J, Thaller G (2009b) The repertoire of equine intestinal alpha-defensins. BMC Genomics 10: 631-644.

Candille SI, Kaelin CB, Cattanach BM, Yu B, Thompson DA, Nix MA, Kerns JA, Schmutz SM, Millhauser GL, Barsh GS (2007) Adefensin mutation causes black coat color in domestic dogs. Science 318:1418-1423.

Chen J, Qi S, Guo R, Yu B, Chen D (2010) Different messenger RNA expression for the antimicrobial peptides beta-defensins between Meishan and crossbred pigs. Mol Biol Rep 37: 1633--1639.

Cormican P, Meade KG, Cahalane S, Narciandi F, Chapwanya A, Lloyd AT, O'Farrelly C (2008) Evolution, expression and effectivness in a cluster of novel bovine beta-defensins. Immunogenet $\mathbf{6 0}$ : 147-156.

Das DK, Sharma B, Mitra A, Kumar A (2005) Molecular cloning and characterization of beta-defensin cDNA expressed in distal ileum of buffalo (Bubalus bubalis). DNA Seq 16: 16--20.

Davis EG, Sang Y, Blecha F (2004) Equine beta-defensin-1: full-lenght cDNA sequence and tissue expression. Vet Immunol Immunopath 99: $127-132$

Davies D, Meade KG, Herath S, Eckersall PD, Gonzalez D, White JO, Conlan RS, O’Farrelly C, Sheldon IM (2008) Toll-like receptor and antimicrobial peptide expression in the bovine endometrium. Reprod Biol Endocrinol 6: 53.

Derache C, Esnault E, Bonsergent C, Le Vern Y, Quéré P, Lalmanach AC (2009a) Differential modulation of beta-defensin gene ex- pression by Salmonella Enteritidis in intestinal epithelial cells from resistant and susceptible chicken inbred lines. Dev Comp Immunol 33:959--966.

Derache C, Labas V, Aucagne V, Meudal H, Landon C, Delmas AF, Magallon T, Lalmanach AC (2009b) Primary structure and antibacterial activity of chicken bone marrow-derived beta-defensins. Antimicrob Agents Chemother 53:4647-4655.

Diamond G, Zasloff M, Eck H, Brasseur M, Maloy WL Bevins CJ (1991) Tracheal antimicrobial peptide, a novel cysteine-rich peptide from mammalian tracheal mucosa: Peptide isolation and cloning of a cDNA. Proc Natl Acad Sci USA 88: 3952-3956.

Diamond G, Jones DE, Bevins CJ (1993) Airway epithelial cells are the site of expression of a mammalian antimicrobial peptide gene. Proc Natl Acad Sci USA 90: 4596-4600.

Diamond G, Kaiser V, Rhodes J, Russell JP, Bevins CL (2000) Transcriptional regulation of beta-defensin gene expression in tracheal epithelial cells. Infect Immun 68: 113-119.

Dreger DL, Schmutz SM (2010) The variant red coat colour phenotype of Holstein cattle maps to BTA27. Anim Genet 41:109-112.

Ebers KL, Zhang CY, Zhang MZ, Bailey RH, Zhang S (2009) Transcriptional profiling avian beta-defensins in chicken oviduct epithelial cells before and after infection with Salmonella enterica serovar Enteritidis. BMC Microbiol 9:153.

Evans EW, Beach FG, Moore KM, Jackwood MW, Glisson JR, Harmon BG (1995) Antimicrobial activity of chicken and turkey heterophil peptides CHP1, CHP2, THP1, and THP3. Vet Microbiol 47: 295-303.

Galindo RC, Ayoubi P, Naranjo V, Gortazar C, Kocan KM, de la Fuente J (2009) Gene expression profiles of European wild boar naturally infected with Mycobacterium bovis. Vet Immunol Immunopathol 129:119-125.

Gallagher DS Jr, Ryan AM, Diamond G, Bevins CL, Womack JE (1995) Somatic cell mapping of beta-defensin genes to cattle syntenic group U25 and fluorescence in situ localization to chromosome 27. Mamm Genome 6:55--556.

Ganz T (2004) Defensins: antimicrobial peptides of vertebrates. C R Biologies 32: 539-549.

Ganz T, Lehrer RI (1995) Defensins. Pharmacol Ther 66: 191-205.

Ganz T, Lehrer RI (1998) Antimicrobial peptides of vertebrates. Curr Opin Immunol 10: 41-44.

Goldammer T, Zerbe H, Aar A, Schuberth HJ, Brunner RM, Kata SR, Seyfert H-M (2004) Miastitis icreases mammary mRNA abudance of $\beta$-defensin 5, toll-like-receptor 2 (TLR2), and TLR4 but not TLR9 in cattle. Clin Diagn Lab Immunol 11: 174-185.

Gong D, Wilson PW, Bain MM, McDade K, Kalina J, Herve-Grepinet V, Nys Y, Dunn IC (2010) Gallin: an antimicrobial peptide member of a new avian defensin family, the ovodefensins, has been subject to recent gene duplication. BMC Immunol 11: 12 .

Gordon YJ, Romanowski EG (2005) A review of antimicrobial peptides and their therapeutic potential as anti-infective drugs. Curr Eye Res 30: 505-515.

Hancock REW (1997) Peptide antibiotics. Lancet 349: 418--422.

Harwig SS, Swiderek KM, Kokryakov VN, Tan L, Lee TD, Panyutich EA, Aleshina GM, Zhao C, Shamova OV, Lehrer RI (1994) Gallinacins: cysteine-rich antimicrobial peptides of chicken leukocytes. FEBS Letters 342: 281-285.

Hasenstein JR, Lamont SJ (2007) Chicken gallinacin gene cluster associated with Salmonella response in advanced intercross line. Avian Dis 51: 561-567.

Helmerhorst EJ, Breeuwer P, van't Hof W, Walgreen-Weterings E, Oomen LC, Veerman EC, Amerongen AV, Abee T (1999) The cellular target of histatin 5 on Candida albicans is the energized mitochondrion. I Biol Chem 274: 7286-7291.

Huttner KM, Bresinski-Caliguri DJ, Mahoney MM, Diamond G (1998a) Antimicrobial peptide expression is developmentally regulated in the ovine gastrointenstinal tract. I Nutr 128: 297S-299S.

Huttner KM, Lambeth MR, Burkin HR, Burkin DJ, Broad TE (1998b) Localization and genomic organization of sheep antimicrobial peptide genes. Gene 206: 85-91.

Iannuzzi L, Gallagher DS, Di Meo GP, Diamond G, Bevins CL, Womack JE (1996) High-resolution FISH mapping of beta-defensin genes to river buffalo and sheep chromosomes suggests a chromosome discrepancy in cattle standard karyotypes. Cytogenet Cell Genet 75: $10-13$.

Jenssen H, Hamill P, Hancock REW (2006) Peptide antimicrobial agents. Clin Microbiol Rev 19: 491-511.

Kagan BL, Selsted ME, Ganz T, Lehrer RI (1990) Antimicrobial defensin peptides form voltage-dependent ion-permeable channels in planar lipid bilayer membranes. Proc Natl Acad Sci USA 87: $210-$ 214.

Kamysz W, Okrój M, Lukasiak J (2003) Novel properties of antimicrobial peptides. Acta Biochim Pol 50: 461-469.

Koczulla AR, Bals R (2003) Antimicrobial peptides: current status and therapeutic potential. Drugs 63: 389-406.

Lehrer RI, Ganz T (1999) Antimicrobial peptides in mammalian and insect host defence. Curr Opin Immunol 11: 23-27. 
Lehrer RI, Ganz T (2002) Defensins of vertebrate animals. Curr Opin Immunol 14: 96-102.

Leszczyńska K (1998) Ocena efektów skojarzonego działania antybiotyków z defensynami oraz mieloperoksydazą na szczepy Staphylococcus aureus. PhD Dissertation, Medical University, Faculty of Medicine, Department of Microbiology, Białystok, Poland (in Polish).

Liang QL, Zhou K, He HX (2010) Retrocyclin 2: a new therapy against avian influenza $\mathrm{H} 5 \mathrm{~N} 1$ virus in vivo and in vitro. Biotechnol Lett 32: 387-392.

Looft C, Paul S, Philipp U, Regenhard P, Kuiper H, Distl O, Chowdhary BP, Leeb T (2006) Sequence analysis of a $212 \mathrm{~kb}$ defensin gene cluster on ECA 27q17. Gene 376: 192-198.

Luenser K, Fickel J, Ludwig A (2005) Evolution of caprine and ovine beta-defensin genes. Immunogenetics 57: 487-498.

Lynn DJ, Bradley DG (2007) Discovery of $\alpha$-defensins in basal mammals. Dev Comp Immunol 31: 963-967.

Ma D, Wang R, Liao W, Han Z, Liu S (2009a) Two Novel Duck Antibacterial Peptides, Avian beta-Defensins 9 and 10, with Antimicrobial Activity. J Microbiol Biotechnol 19: 1447-1455.

Ma D, Wang R, Liao W, Han Z, Liu S (2009b) Identification and characterization of a novel antibacterial peptide, avian beta-defensin 2 from ducks. J Microbiol 47: 610-618.

Mallow EB, Harris A, Salzman N, Russell JP, DeBerardinis RJ, Ruchelli E, Bevins CL (1996) Human enteric defensins. J Biol Chem. 271: 4038-4045.

Meade KG, Higgs R, Lloyd AT, Goles S, O'Farrelly C (2009) Differential antimicrobial peptide gene expression patterns during early chicken embryo;ogical development. Dev Comp Immunol 33: 516-524.

Milenkovic D, Oustry-Vaiman A, Lear TL, Billault A, Matiat D, Piumi F, Schibler L, Cribiu E, Guerin G (2002) Cytogenetic localization of 136 genes in the horse: comparative mapping with the human genome. Mamm Genome 13: 524-534.

Nava GM, Escorcia M, Cantañeda MP (2009) Molecular diversity of the antimicrobial domain of beta-defensin 3 and homologous peptides. Comp Funct Genomomics doi:10.1155/2009/983636.

Patil A, Hughes AL, Zhang G (2004) Rapid evolution and diversification of mammalian $\alpha$-defensins as revealed by comparative analysis of rodent and primate genes. Physiol Genomics 20: 1-11.

Pawlik A, Sender G, Korwin-Kossakowska A (2009) Bovine lactoferrin gene polymorphism and expression in relation to mastitis resistance - a review. Anim Sci Pap Rep 27: 263-271.

Perron GG, Zasloff M, Bell G (2006) Experimental evolution of resistance to an antimicrobial peptide. Proc R Soc B 273: 251-256.

Rice WG, Ganz T, Kinkade JM, Selsted ME J., Lehrer RI, Parmley RT (1987) Defensin-rich dense granules of human neutrophils. Blood 70: $757-765$.

Roosen S, Exner K, Paul S, Schroeder J-M, Kalm E, Looft C (2004) Bovine $\beta$-defensins: Identification and characterisation of novel bovine $\beta$-defensin genes and their expression in mammary gland tissue. Mamm Genome 15: 834-842.

Russell JP, Diamond G, Tarver AP, Scanlin TF, Bevins CL (1996) Coordinate induction of two antibiotic genes in tracheal epithelial cells exposed to the inflammatory mediators lipopolysaccharide and tumor necrosis factor alpha. Infect Immun 66: 1045-1056.

Ryan LK, Rhodes J, Bhat M, Diamond G (1998) Expression of beta-defensin genes in bovine alveolar macrophages. Infect Immun 66: 878-881.

Ryniewicz Z, Zwierzchowski L, Bagnicka E, Flisikowski K, Maj A, Krzyżewski J, Strzałkowska N (2003) Association of the polymorphism at defensin gene loci with dairy production traits and milk somatic cell count in Black-and-White cows. Anim Sci Pap Rep 21: 209-222.

Sang Y, Blecha F (2009) Porcine host defense peptides: expanding repertoire and functions. Dev Comp Immunol 33:334--343

Sang Y, Patil AA, Zhang G, Ross CR, Blecha F (2006) Bioinformatic and expression analysis of novel porcine beta-defensins. Mamm Genome 17: 332-339.

Sharma A, Dev K, Kumar A (2006) Cloning and characterization of goat lingual antimicrobial peptide. GenBank DQ836129.

Schneider JJ, Unholzer A, Schaller M, Schaefer-Kortig M, Kortig HC (2005) Human defensins. J Mol Med 83: 587-595.

Schonwetter BS, Stolzenberg ED, Zasloff MA (1995) Epithelial antibiotics induced at sites of inflammation. Science 267: 1645-1648.

Selsted ME, Tang YQ, Morris WL, McGuire PA, Novotny MJ, Smith W, Henschen AH, Cullor JS (1993) Purification, promary structures, and antibacterial activities of beta-defensins, a new family of anti- microbial peptides from bovine neutrophils. I Biol Chem 268: 66416648.

Shai Y (1999) Mechanism of the binding, insertion and destabilization of phospholipid bilayer membranes by alpha-helical antimicrobial and cell non-selective membrane-lytic peptides. Biochim Biophys Acta 1462: $55-70$.

Shi J, Zhang G, Wu H, Ross CR, Blecha F, Ganz T (1999) Porcine epithelial beta-defensin 1 is expressed in the dorsal tongue at antimicrobial concentrations. Infect Immun 67: 3121-3127.

Soman SS, Arathy DS, Sreekumar E (2009) Discovery of Anas platyrhynchos avian beta-defensin 2 (Apl_AvBD2) with antibacterial and chemotactic functions. Mol Immunol 46: 2029-2038.

Stolzenberg ED, Anderson GM, Ackermann MR, Whitlock RH, Zasloff M (1997) Epithelial antibiotic induced in states of disease. Proc Natl Acad Sci USA 94: 8686-8690.

Sugiarto H, Yu PL (2007) Mechanisms of action of ostrich beta-defensins against Escherichia coli. FEMS Microbiol Lett 270: 195-200.

Sun CQ, Arnold R, Fernandez-Golarz C, Parrish AB, Almekinder T, He J, Ho SM, Svoboda P, Pohl J, Marshall FF, Petros JA (2006) Human beta-defensin-1, a potential chromosome $8 \mathrm{p}$ tumor suppressor: control of transcription and induction of apoptosis in renal cell carcinoma. Cancer Res 66: 8542-8549.

Swanson K, Gorodetsky S, Good L, Davis S, Musgrave D, Stelwagen K., Farr V, Molenaar A (2004) Expression of $\beta$-defensin mRNA, Lingual Antimicrobial Peptide, in bovine mammary epithelial tissue is induced by mastitis. Infect Immun 72: 7311-7314.

Swinburne JE, Boursnell M, Hill G, Pettitt L, Allen T, Chowdhary B, Hasegawa T, Kurosawa M, Leeb T, Mashima S, Mickelson JR, Raudsepp T, Tozaki T, Binns M (2006) Single linkage group per chromosome genetic linkage map for the horse, based on two three-generation, full-sibling, crossbred horse reference families. Genomics 87: 1-29.

Tang YQ, Yuan J, Osapay G, Osapay K, Tran D, Miller CJ, Outllette AJ, Selsted ME (1999) A cyclic antimicrobial peptide produced in primate leucocytes by the ligation of two truncated alpha-defensin. Science, 286: 489-502.

Tarver AP, Clark DP, Diamond G, Russell JP, Erdjument-Bromage H, Tempst P, Cohen KS, Jones DE, Sweeney RW, Wines M, Hwang S, Bevins CL (1998) Enteric beta-defensin: Molecular cloning and characterisation of a gene with inducible intenstinal epithelial cell expression associated with Cryptosporidium parvum infection. Infect Immun 66: 1045-1056.

Van Dijk A, Veldhuizen EJA, Kalkhove SIC, Tjeerdsma-van Bokhoven JLM, Romijn RA, Haagsman HP (2007) The B-Defensin Gallinacin-6 Is Expressed in the Chicken Digestive Tract and Has Antimicrobial Activity against Food-Borne Pathogens. Antimicrob Agents Chemother 51: 912-922.

Veldhuizen EJQ, Rijnders M, Claassen EA, van Dijk A, Haagsman HP (2008a) Porcine $\beta$-defensin 2 displays broad antimicrobial activity agains pathogenic intestinal bacteria. Mol Immunol 45: 386-394.

Veldhuizen EJQ, Koomen I, Ultee T, van Dijk A, Haagsman HP (2008b) Salmonella serovar specific upregulation of porcine defenins 1 and 2 in a jejunal epithelial cell line. Vet Microbiol (doi:10.1016/j. vetmic.2008.09.072).

Wiechuła BE, Tustanowski JP, Martirosian G (2006) Antimicrobial peptides. Wiad Lek 59: 542-547 (in Polish)

Wojdak-Maksymiec K, Kmieć M, Zukiewicz A (2006) Associations between defensin polymorphism and somatic cell count in milk and milk utility traits in Jersey dairy cows. J Vet Med A Physiol Pathol Clin Med. 53:495-500.

Yang DM, Chertov O, Bykowskaia SN., Chen Q, Buffo MJ, Shogan J, Anderson M, Scroder JM, Wang JM, Howard OM, Oppenheim JJ (1999) BETA defensins: linking innate and adaptive immunity through dendric and T cell CCR6. Science 286: 525-528.

Zhang G, Hiraiwa H, Yasue H, Wu H, Ross CR, Troyer D, Blecha F (1999) Cloning and characterisation of the gene for a new epithelial beta-defensin. Genomic structure, chromosomal localization, and evidence for its constitutive expression. J Biol Chem 274: 24031-24037.

Zhao C, Nguyen T, Liu L, Sacco RE, Brodgen KA, Lehrer RI (2001) Gallinacin-3, an inducible epithelial beta-defensin in the chicken. Infect Immun 69: 2684-2691.

Zhao C, Nguyen T, Liu L, Shamova O, Brodgen K, Lehrer RI (1999) Differential expression of Caprine beta-defensin in digestive and respiratory tissues. Infect Immun 67: 6221-6224. 